\title{
legelivet
}

På disse sidene i Tidsskriftet - legelivet - finner du stoff om legers liv.

Her er det presentasjon av arbeidssteder, nyhetssaker, nye doktorgrader,

nye spesialister og minneord. Alt samlet på ett sted - så du kan følge enda bedre med.

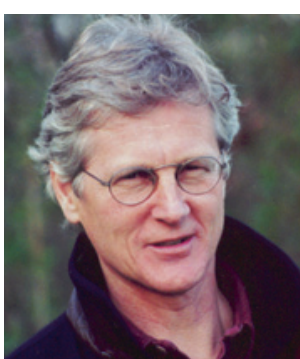

Karl Otto Nakken Foto: Privat

Karl O. Nakken (f. 1945) er lege ved Nevroklinikken, Oslo universitetssykehus

\section{Mimring i doktorklubben}

\author{
I doktorklubben har det lett for å bli mye mimring om forgangne tider.
}

Det er pussig å registrere hvor godt klubbens medlemmer husker episoder fra studietiden, mens stoff fra nyere tid ikke sitter like godt. Et medlem hadde en teori om at det må være et inverst forhold mellom prostatastørrelsen og hippocampus - jo større prostata, desto mer atrofiske hippocampi.

Flere av medlemmene var i studietiden med i Medisinsk Paradeorchæster. Her er det som kjent to kategorier musikanter, nemlig de som kan spille og de såkalte naturtalentene (1). Våre medlemmer hørte så avgjort til den siste kategori. Orkesteret, hvis motto er «Det blæs i Noreg», er kjent for å spille når det vil, hvor det vil og for hvem det vil. Under møtene i doktorklubben får vi, i minste detalj, servert de besynderligste historier fra orkesterets konserter. Disse historiene blir ikke mindre fargerike med årene. Tvert imot. At de samme historiene blir fortalt på nytt og på nytt, hver gang med noe forskjellig innhold, bærer vi alltid over med. Ofte tar jeg meg i å tenke at vi nok er havnet i repetisjonsalderen.

Et av medlemmene har et varig minne eller sekvele - fra tiden i Paradeorchæsteret. Under en av orkesterets konserter, midt i fremføringen av den smektende slageren La Paloma, klarte han med cymbalene å kutte av seg ytre del av venstre hånds lillefinger. Da han etter mye om og men kom seg til legevakten for å få sydd på fingertuppen, hadde han klart å somle den bort! I ettertid mente han tapet var å betrakte som et naturlig offer på kunstens alter. Han mente dessuten at han var opphavet til uttrykket «Han hadde en finger med i spillet». Han bedyret også at han siden aldri hadde vært langfingret.

I klubben er det en uskreven lov at vi ikke snakker om egne sykdommer eller barnebarna. Det begås til stadighet lovbrudd.

På det siste møtet kunne et av medlemmene berette om et eiendommelig fenomen. Under tømming av tarmen fikk han regelmessig sekresjon fra høyre nesebor. Han hevdet det måtte eksistere en anonasal refleks. Som vanlig var det vanskelig å ta mannen på alvor. Både proktologen og jeg som nevrolog måtte innrømme at vi aldri hadde hørt om en slik refleksbue. Men det har kanskje noen av leserne?

\section{Karl 0. Nakken}

karln@ous-hf.no

Litteratur

1. Rake M, Lærum OD. Lar seg bare stoppe av ridende politi til hæst - Medisinsk Paradeorchæster fyller 50 år. Tidsskr Nor Legeforen 2011; 131: 1052-5. 